\title{
Responses of terrestrial herb assemblages to weeding and fertilization in cacao agroforests in Indonesia
}

\author{
Daniele Cicuzza • Yann Clough • \\ Sri Sudarmiyati Tjitrosoedirdjo $\cdot$ Michael Kessler
}

Received: 9 July 2010/Accepted: 1 November 2011/Published online: 11 November 2011

(C) Springer Science+Business Media B.V. 2011

\begin{abstract}
Terrestrial herbs are important ecological components in tropical agroforests, but little is known about how they are affected by agricultural management. In cacao agroforests of Central Sulawesi, Indonesia, we studied the change in herb species richness, cover, and biomass over 3 years in 86 subplots subjected to high and low weeding frequency as well as fertilized and non-fertilized treatments. We recorded 111 species with rapid changes in species composition between the 3 years. Species richness increased sharply in the 2nd year, presumably as a result of changes in the management with the experimental regimes, and decreased in the 3rd, probably due to competitive exclusion. Species richness, cover, and biomass were all significantly higher in the infrequently weeded plots than in the frequently weeded ones, but there were only slight responses to
\end{abstract}

Electronic supplementary material The online version of this article (doi:10.1007/s10457-011-9456-6) contains supplementary material, which is available to authorized users.

D. Cicuzza $(\square) \cdot$ M. Kessler

Institute of Systematic Botany, University of Zurich, Zurich, Switzerland

e-mail: daniele.cicuzza@systbot.uzh.ch

Y. Clough

Agroecology, University of Göttingen, Göttingen,

Germany

\section{S. S. Tjitrosoedirdjo}

Department of Biology, Bogor Agricultural University,

Bogor, Indonesia the fertilization treatment. An indicator species analysis recovered 45 species that were typical for a given year and a further eight that were typical for certain treatments, but these species showed no clear patterns relative to their ecology or biogeography. We conclude that the herb assemblages in cacao agroforests are quite resilient against weeding, but that the cover of species shifts rapidly in response to management.

Keywords Weed management - Cacao . Agroforests · Sulawesi

\section{Introduction}

Tropical agroforests, in which mostly coffee and cacao are cultivated under a canopy of shade trees, cover approximately 18 million hectares worldwide and are of oustanding economic and ecological importance (Donald 2004). Agroforests typically harbour a high level of biodiversity (Bhagwat et al. 2008; Siebert 2000), including a large number of terrestrial herbaceous plants (Steffan-Dewenter et al. 2007). Agroforestry can offer a number of ecosystem services that alleviate poverty in developing countries (Jose 2009), including soil erosion protection, increase of soil fertility (Partey 2011; Saito et al. 2008), and $\mathrm{CO}_{2}$ storing (Esmail and Oelbermann 2011). Because herbs compete with the crop species for light, water, and nutrients especially when trees are young, and can also harbour diseases and pests, farmers commonly control 
herb populations by manual weeding or by applying herbicides (Aguillar et al. 2003). On the other hand, herbs can be important host plants for insect pollinators or natural antagonists of pests and diseases (Bos et al. 2007; Perfecto and Snelling 1995; Philpott and Armbrecht 2006). Moreover, flowering plants are important to maintain high bee species richness and result in a better pollination in coffee plantations (Klein et al. 2003). Herbaceous plants have often been neglected in biodiversity inventories of cacao and coffee plantations, with studies mostly focusing on trees, insects and vertebrates (Bisseleua et al. 2008; Philpott et al. 2008; Tscharntke et al. 2008; Abrahamczyk et al. 2008; Greenberg et al. 2000; Faria and Baumgarten 2007; Weist et al. 2010).

The composition and diversity of herb assemblages in agroforests are influenced by management practices. Thus, the density and composition of the shade tree canopy ranges from rustic systems established under the thinned canopy of natural shade trees to technified systems completely lacking shade trees. The density and diversity of terrestrial herbs typically increases in plantations with a more open canopy (Zapfack et al. 2002). However, many of the species found in sunny plantations are weedy, pantropical species (Zapfack et al. 2002) whereas more densely shaded plantations generally harbour species more typically found in forests (Bobo et al. 2006), have more restricted ranges (Lozada et al. 2008), and are of higher conservation concern (Cicuzza et al. 2011).

In the scope of an interdisciplinary project addressing ecological and socioeconomic aspects of Indonesian cacao agroforests (Clough et al. 2011), over 2 years we studied how management practices influence the diversity and composition of the terrestrial herb assemblages. We used the data to address questions regarding the impact of management in the cacao agroforests on herbaceous plant communities. We asked the following questions:

(i) Do species richness, cover, biomass, and composition of the terrestrial herb assemblages change over 2 years in relation to two management aspects (weeding, fertilization)?

(ii) Are particular species typical for specific management regimes?

(iii) Is there a relationship between the management regimes and the presence of native or weedy herb species?

\section{Materials and methods}

Study area

The study was conducted between 400 and $1000 \mathrm{~m}$ in the Kulawi and Palolo valleys adjacent to Lore Lindu National Park, Central Sulawesi (Fig. 1). Monthly temperatures range between minima of $12-17^{\circ} \mathrm{C}$ and maxima of $26-35^{\circ} \mathrm{C}$, mean annual precipitation is $2000 \mathrm{~mm}$ (The Nature Conservation 2004). Beginning in the eighties, more than 7500 hectares of cacao plantations have been established in and around the national park (Erasmi et al. 2004). Plantations mostly have an open to dense canopy of shade trees, which are either remnant trees from the native primary or old secondary forest (rustic cacao), polycultural stands of planted fruit or timber trees such as candlenut Aleurites moluccana (L.) Willd., rambutan Nephelium lappaceum L., Persea americana Mill., langsat (longan) Lansium domesticum Correa, and durian Durio zibethinus Rumph. ex Murray (planted shade cacao), or species-poor stands of the leguminous trees Gliricidia sepium (Jacq) Kunth ex Walp. and Erythrina subumbrans (Hassk.) Merr., with a further management intensification to the complete removal of trees for full sun production (technified cacao) (Rice and Greenberg 2000; Kessler et al. 2005; Clough et al. 2009).

Vegetation sampling

Our study was part of a larger project aimed at elucidating the relationships of cacao management and yield as well as biodiversity (Clough et al. 2011). We rented 43 plots, 22 in Kulawi and 21 in Palolo valley, of $40 \mathrm{~m} \times 40 \mathrm{~m}$ each, from the local farmers from July 2006 to October 2008. Plantations were selected to cover the widest possible range of elevation, shade tree density and diversity, and distance from the natural forest and were managed independently before the beginning of our experiment (Clough et al. 2009). Plots were not treated with herbicides in the 6 month before the onset of the project. Twenty one plots were randomly assigned to a frequent manual weeding regime (every 2 months), the other 22 to infrequent manual weeding (every 6 months). Each plot was further divided into two $20 \mathrm{~m} \times 40 \mathrm{~m}$ subplots and one half fertilized twice a year with urea fertilizer $(46 \% \mathrm{~N})$ placing $217 \mathrm{~g}$ urea $(100 \mathrm{~g} \mathrm{~N})$ per 

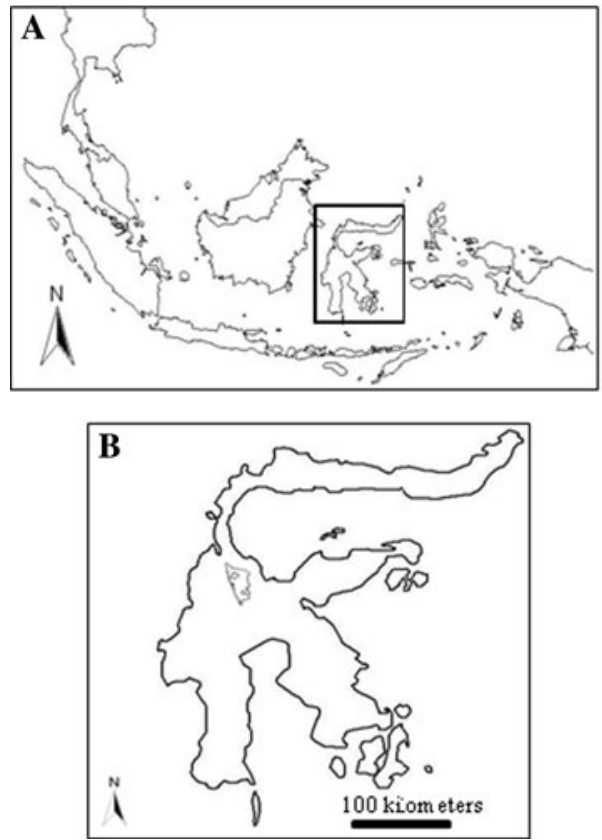

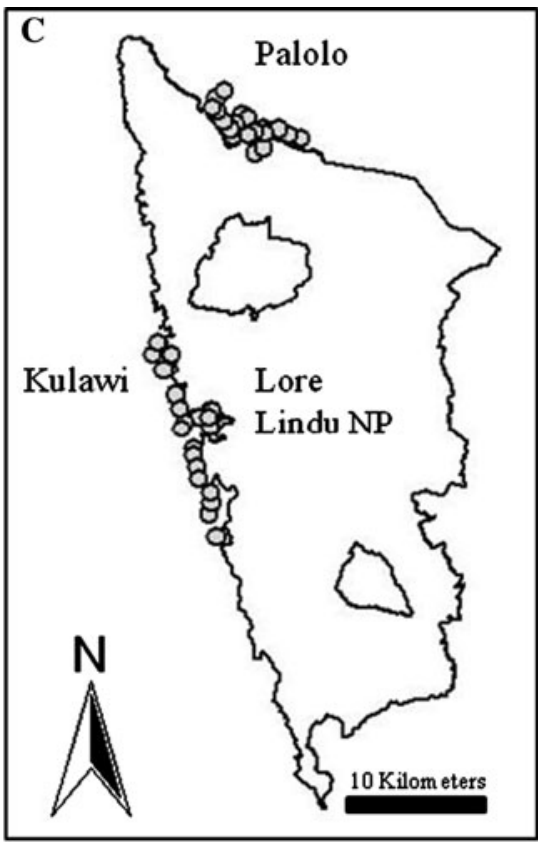

Fig. 1 Maps of study area: a The Malay archipelago with the island of Sulawesi highlighted; b Sulawesi with the Lore Lindu National Park boundary; c Lore Lindu National Park with the position of the 43 research plots (circles) in Palolo and Kulawi valleys

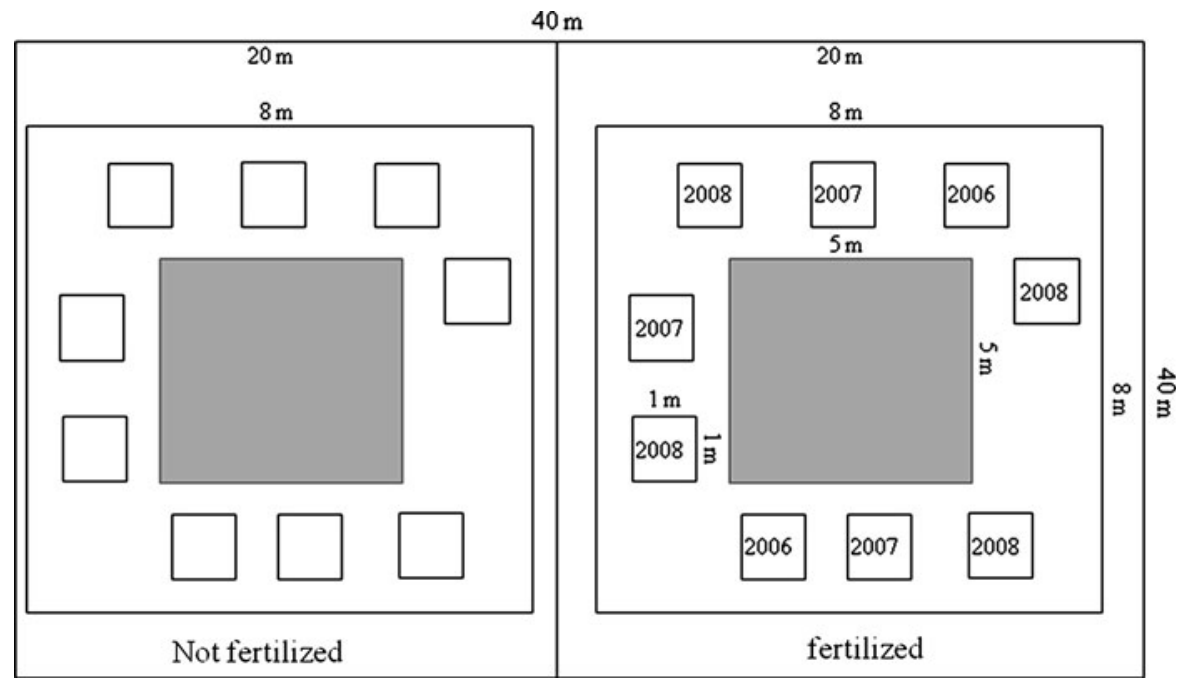

Fig. 2 Plot design; the overall plot of $40 \times 40 \mathrm{~m}^{2}$ was subdivided into two fertilization treatment subplots including in turn each a plot of $8 \times 8 \mathrm{~m}^{2}$ where our herb study was carried

cacao tree with aliquots placed into 10 holes around each tree.

Field work for the present study was conducted during the months of September and October of 2006, 2007 and 2008. In 2006, we established in each plot two subplots of $8 \mathrm{~m} \times 8 \mathrm{~m}$ each, one in the fertilized out. The $5 \times 5 \mathrm{~m}^{2}$ plot inside (grey) was used to monitor the herb assemblages. Biomass samples were taken in the $1 \times 1 \mathrm{~m}^{2}$ plots surrounding the monitoring area. Graph not to scale

and the other in the non-fertilized half (Fig. 2). In the center of each subplot, we roped off an area of $5 \mathrm{~m} \times 5 \mathrm{~m}$ which was not disturbed except for the management activities of the cacao plantation. This area was used to monitor the composition of the herb vegetation by recording all terrestrial herb species and 
estimating their average height and total cover (in classes: 0-1, 1-5, 5-10, 10-20, 20-40, 4-60, 60-80, 80-100\%). Voucher specimens were collected and deposited in Herbarium Celebense, Palu (CEB), Herbarium Bogoriense, Bogor (BO), and the herbaria of Göttingen (GOET), Leiden (L), Zürich (Z), and UC Berkeley (UC, ferns only). In the peripheral area of the plots in Kulawi valley, we established 9 quadrats of $1 \mathrm{~m} \times 1 \mathrm{~m}$ each (Fig. 2). These were sampled destructively in each field season ( 2 in 2006, 3 each in 2007 and 4 in 2008) and samples were separated, dried and weighted by below- and above-ground components.

Data analysis

To estimates sampling completeness, we used the program Estimates $S$ v 8.2 (Colwell 2008), applying the mean of eight species richness estimators (ACE, ICE, CHAO2, JACK1, JACK2, BOOTSTRAP, MMMEAN, MMRUNS) (Herzog et al. 2002; Chiarucci et al. 2003).

To address changes in species richness, cover, and biomass in relation to the sampling years and to the management regimes, we performed repeated-measures ANOVAs separately for fertilization and weeding. To identify changes in species richness, cover and biomass we also used generalized linear mixed models (Bloker et al. 2009) obtaining quantitatively similar results to those of the repeated-measures ANOVAs; these results are not further shown here. To assess changes in species composition we used a principal component analysis (PCA) based on the Bray-Curtis similarity index (Oksanen et al. 2007). Further, we used Analyses of Similarity (ANOSIM) (Clarke et al. 2008) to assess if shifts in species composition between years or between management regimes where significant. Finally, we used indicator species analyses (Bakker 2008; Mouillon et al. 2002) to determine which species were characteristic for different years or management regimes. Indicator species were classified as typically growing in forests or in open habitats as well as being pantropical or having a geographical distribution restricted to Malayan archipelago based on personal field and herbarium experience (Cicuzza et al. 2011) and information from the literature. Analyses were performed in R (R Development Core Team 2007), with an additional function provided by $\mathrm{R}$ package vegan (Oksanen et al. 2007). Indicator species analysis was conducted with PCOrd 5.0 (Mc Cune Mefford 1999).

\section{Results}

Species richness, cover, and biomass

During the 3 years, we recorded 111 herbs species. The mean of the eight species richness estimators was $120 \pm 6$, indicating that our 43 study plots included about $90 \%$ of the herb species occurring in cacao plantations in the study region. Comparing the years, 56 species were recorded in 2006, 90 in 2007, and 72 in 2008; 32 species were recorded in all 3 years, but there was also strong turnover in species composition, with 13 species recorded only in 2006, 17 in 2007 and 10 in 2008 (Fig. S1).

Species richness was significantly different between weeding treatments but not between
Table 1 Repeatedmeasures ANOVAs comparing mean values of species richness, ground cover, above- and belowground biomass between years for two different experimental treatments (fertilization; weeding intensity)

\begin{tabular}{|c|c|c|c|c|c|c|c|c|}
\hline & \multicolumn{2}{|c|}{$\begin{array}{l}\text { Species } \\
\text { richness }\end{array}$} & \multicolumn{2}{|l|}{ Cover } & \multicolumn{2}{|c|}{$\begin{array}{l}\text { Above-ground } \\
\text { biomass }\end{array}$} & \multicolumn{2}{|c|}{$\begin{array}{l}\text { Below-ground } \\
\text { biomass }\end{array}$} \\
\hline & $F$ & $P$ & $F$ & $P$ & $F$ & $P$ & $F$ & $P$ \\
\hline \multicolumn{9}{|l|}{ Fertilized treatment } \\
\hline Years & 48.9 & 0.00 & 21.96 & 0.00 & 4.22 & 0.17 & 7.69 & 0.00 \\
\hline Fertilization & 0.03 & 0.85 & 1.20 & 0.27 & 4.04 & 0.05 & 2.70 & 0.10 \\
\hline Years-fertilization, interaction & 0.11 & 0.90 & 0.66 & 0.52 & 0.09 & 0.92 & 0.09 & 0.91 \\
\hline \multicolumn{9}{|l|}{ Weeding treatment } \\
\hline Years & 48.2 & 0.00 & 22.92 & 0.00 & 5.00 & 0.01 & 9.92 & 0.00 \\
\hline Weeding & 17.14 & 0.00 & 0.64 & 0.46 & 21.06 & 0.00 & 26.26 & 0.00 \\
\hline Years-weeding, interaction & 2.29 & 0.10 & 4.61 & 0.01 & 1.25 & 0.29 & 4.19 & 0.17 \\
\hline
\end{tabular}


fertilization treatments (Table 1). In 2007 and 2008, weeded plots had significantly fewer species than nonweeded plots (Fig. 3). Comparing the years, herb cover increased significantly over the years in the weeding treatment but not in the fertilization treatment
(Table 1; Fig. 3). Below- and above-ground biomass increased in both treatments: weeding and fertilizing the cacao plantation showed a positive and significant increase in biomass, differing between the years of treatment (Table 1; Fig. 3).
Fig. 3 Changes in traits of herb assemblages under different management regimes over 2 years of study. Box plots show mean (bold line), the 25th and 75th percentile (box), $95 \%$ of confidence interval (whiskers), and outliers (dots). Categories with different superscript letters are significantly different from each other (Tukey's HSD). $C$ control, $F$ fertilized, $H$ high weeding frequency; $L$ low weeding frequency
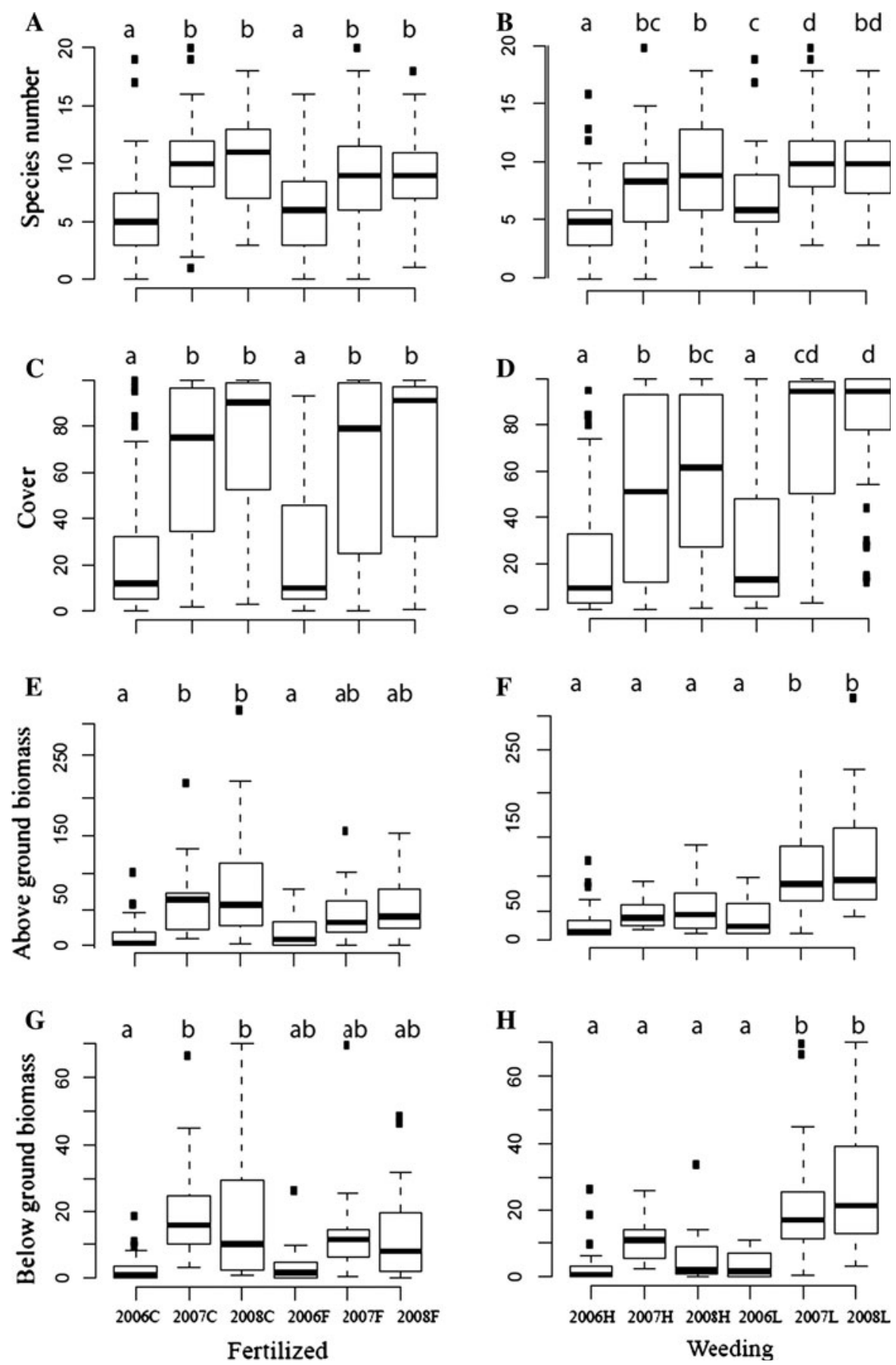
Species composition

Species composition of the plots shifted significantly over the years (ANOSIM: $R=0.24, P=0.01$ ), although this trend was mainly driven by a few plots, while the majority of plots only showed marginal changes (Fig. 4). An associated Indicator Species Analysis found that 45 species had significantly higher cover in a given year: 8 species in 2006, 15 in 2007, and 22 in 2007 (Table 2). However, we found no significant differences in the frequency of forest-based versus open-country species ( $G$-test, $G=1.44$, $P>0.05)$ nor between pantropical and Malesian species ( $G$-test, $G=0.93, P>0.05$ ). Considering the experimental treatments, we found marginally significant shifts in species composition relative to weeding (ANOSIM, $R=0.018, P=0.06$ ) but not relative to fertilization $(R=-0.04, P=0.90)$. The indicator species analysis found five species with significantly higher frequency in plots weeded only every 6 months, three species typical for frequently weeded plots, and 2 species for plots that were fertilized (Table 3).

\section{Discussion}

Overall, the results of our study can be summarized as follows: species richness, cover, biomass, and

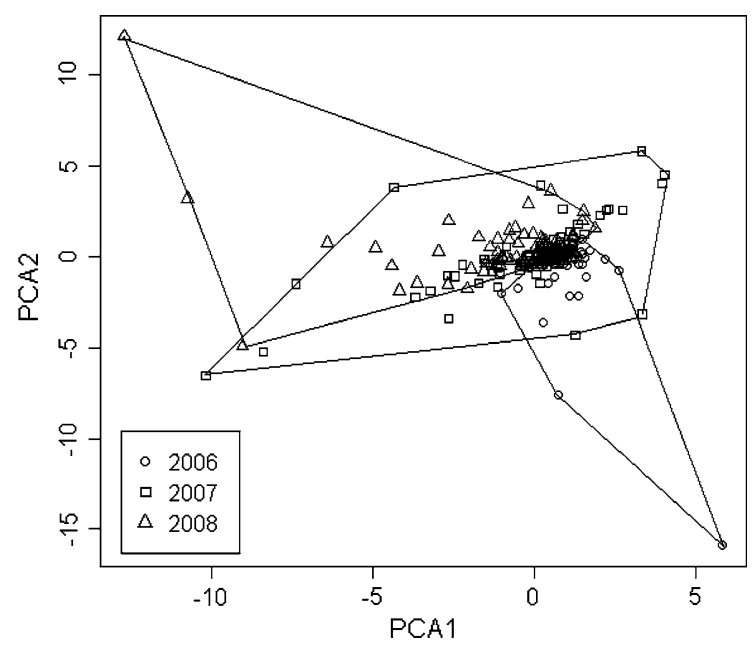

Fig. 4 Principal component analysis (PCA) of study plots based on the species abundance over the 3 years of study. Note the shift in species composition from the first to the 3rd year of the study community composition all changed markedly between years and to a lesser degree between plots with frequent versus infrequent weeding, and with a minor effect for the fertilization treatments. The changes over the years can be explained by differences in management techniques in our experiment relative to the management conducted by the local farmers. In particular, farmers commonly use chemical herbicides to combat herbs. The increase in cover and species numbers between 2006 and 2007 was thus mainly the consequence of the stop of use of herbizides. Since most of the species newly recorded in 2007 are perennial rhizomatous herbs that were found as mature individuals, we assume that most of them were already present at the onset of the experiment but were simply not visible during sampling due to previous use of herbicides. Only two annual Asteraceae species, Bidens pilosa L. and Crassochepalum crepidioides (Benth.) Moore, played an important role in the herb assemblages, but only the latter increased in the course of the experiment. Thus, much of the increase of species numbers between the first 2 years is best explained by the full aboveground development of plants that were already there. The changes between the second and the 3 years in turn may reflect the competitive exclusion of some species by weedy species that, under reduced weed management intensity, could reach high cover and dominate the assemblages.

Although fertilization is well known to affect the composition of terrestrial herb assemblages (Efthimiadou et al. 2009), in our experiment we only observed a small, but not statistically significant, increase of species number. However, the effect of fertilization was evident for both above- and belowground biomass. The fern Diplazium esculentum (Retz.) Sw. and the Urticaceae Elatostema parvum (Blume) Miq. Both increased significantly in the fertilized plots in the last year. Both of these are typically found in damp, nutrient-rich habitats such as road culverts and may thus be expected to respond positively to fertilization.

Contrary to our expectations, we did not find any directional shifts in the frequency of light- versus shade-loving or widespread versus Malesian species over the course of the experiment. Possibly, these aspects are more closely linked to the density of natural forest trees in the plantations and the distance to natural forest, as previously documented in the 
Table 2 Results of the indicator species analysis for the 3 years of treatment in cacao agroforestry systems

\begin{tabular}{|c|c|c|}
\hline 2006 & 2007 & 2008 \\
\hline Bidens pilosa $\mathrm{L}^{\mathrm{b}, \mathrm{d}}$ & Axonopus compressus (Sw.) P. Beauv. ${ }^{\mathrm{a}, \mathrm{d}}$ & Adenostemma lavenia (L.) Kuntze \\
\hline Commelina difformis L. ${ }^{\mathrm{b}, \mathrm{c}}$ & Borreria laevis (Lam.) Griseb ${ }^{\mathrm{b}, \mathrm{d}}$ & Aracea sp. \\
\hline Costus speciosus (J. König) Sm. ${ }^{\text {b,c }}$ & Christella parassitica (L.) Holttum ${ }^{\mathrm{b}, \mathrm{c}}$ & Asplenium nidus $\mathrm{L}^{\mathrm{a}, \mathrm{d}}$ \\
\hline Emilia sonchifolia (L.) DC. ${ }^{\text {b,c }}$ & Cyrtococcum accrescens (Trin.) Stapf. ${ }^{\mathrm{a}, \mathrm{c}}$ & Asteraceae sp. \\
\hline Impatient platypetala ssp. Platypetala ${ }^{\mathrm{a}, \mathrm{c}}$ & Crassocephalus crepidioides (Beth.) S. Moore ${ }^{\mathrm{b}, \mathrm{d}}$ & Begonia $^{\mathrm{a}, \mathrm{c}}$ \\
\hline Pogonatherum crinitum (Thunb.) Steud. & Cyathula prostrata (L.) Blume $\mathrm{b}^{\mathrm{b}, \mathrm{d}}$ & Borreria sp. \\
\hline Schismatoglottis dorensis Gibbs ${ }^{\mathrm{a}, \mathrm{c}}$ & Cynedrella nodiflora (L.) Gaertn. ${ }^{\mathrm{b}, \mathrm{d}}$ & Centella asiatica (L.) Urb. ${ }^{\mathrm{b}, \mathrm{d}}$ \\
\hline \multirow{14}{*}{$\begin{array}{l}\text { Sphaerostephanos invisus (G.Forst.) } \\
\text { Holttum }^{\mathrm{b}, \mathrm{d}}\end{array}$} & Elatostema parvum (Blume) Miq ${ }^{\mathrm{a}, \mathrm{c}}$ & Centotheca lappacea (L.) Desv. ${ }^{\mathrm{a}, \mathrm{d}}$ \\
\hline & Hygrophila sp. & Commelina sp. ${ }^{a}$ \\
\hline & Impatient platipetala Lindl. ${ }^{\mathrm{a}, \mathrm{c}}$ & Commelina benghalensis $\mathrm{L}^{\mathrm{b}, \mathrm{d}}$ \\
\hline & Impatient platipetala var. Aurantica $\mathrm{a}^{\mathrm{a}, \mathrm{c}}$ & Convulvulacae sp. \\
\hline & Passiflora foetida $\mathrm{L}^{\mathrm{b}, \mathrm{d}}$ & Curculigo latifolia Dryand ${ }^{\mathrm{b}, \mathrm{d}}$ \\
\hline & Trichosanthes trifolia (L.) Merr. ${ }^{\mathrm{a}, \mathrm{c}}$ & Diplazium asperum Blume $\mathrm{e}^{\mathrm{b}, \mathrm{c}}$ \\
\hline & Urochloa glumaris (Trin.) Veldk. ${ }^{\mathrm{a}, \mathrm{c}}$ & Diplazium esculentum (Retz.) Sw. b,d \\
\hline & & Elephantopus scaber L. ${ }^{\mathrm{b}, \mathrm{d}}$ \\
\hline & & Impatient radicata Zoll. ${ }^{\mathrm{a}, \mathrm{c}}$ \\
\hline & & Labiata sp. \\
\hline & & Nephrolepis biserrata (Sw.) Schott ${ }^{\mathrm{a}, \mathrm{c}}$ \\
\hline & & Nephrolepis falciformis J. Sm. ${ }^{\mathrm{a}, \mathrm{c}}$ \\
\hline & & Paspalum conjugatum P. J. Bergium ${ }^{\mathrm{b}, \mathrm{c}}$ \\
\hline & & Selaginella caudata (Desv.) Spring ${ }^{\mathrm{a}, \mathrm{c}}$ \\
\hline
\end{tabular}

a Species typically found in forest habitats

b Species typically found in non-forest habitats

c Species with distribution restricted to the Malesian region

d Pantropical species

Table 3 Results of the indicator species analysis for the different treatments

\begin{tabular}{lll}
\hline Low weed treatment & High weed treatment & Fertilized \\
\hline Microsorum scolopendria (Burm. F.) Copel. (1) & Bidens pilosa L. (2) & Diplazium esculentum (Retz.) Sw. (3) \\
Alocasia balgooyi A. Hay (2) & Cyathula prostrata (L.) Blume (3) & Elatostema parvum (Blume) Miq (3) \\
Borreria sp. (3) & Adenostemma lavenia (L.) Kuntze (3) & - \\
Cyrtococcum accrescens (Trin.) Stapf. (3) & - & - \\
Lygodium circinnatum (Burm.) Sw. (3) & - & - \\
\hline
\end{tabular}

The non-fertilized plots had no indicator species. Numbers indicate in which year the species were significantly more abundant: $1=2006,2=2007,3=2008$

study region (Steffan-Dewenter et al. 2007; Cicuzza et al. 2011), rather than to management practices.

In conclusion, we found that the herb assemblages in the studied cacao agroforests were strongly influenced by chemical and mechanical weeding but only slightly by fertilization. A less frequent weeding management can thus not only preserve local herbaceous species, limiting the introgression of weedy species (Banful et al. 2007), but may affect the diversity and community composition of amphibians 
and reptiles (Wanger et al. 2009) and insects (Wielgoss et al. 2010). A negative effect of intensive weeding is evidenced by changes in water balance, litter decomposition, and nutrient cycling of the upper soil layer (Watanabe et al. 2007; Smiley and Kroschel 2010).

Acknowledgments This study was funded by the German Research Foundation (DFG), grant SFB-552 STORMA (Stability of Rainforest Margins) http://www.uni-goettingen.de/ de/40515.html. Herb species identification was conducted partly at the Herbarium of Leiden supported by Synthesys NL-TAF 3536. We thank Stefan Köhler, head of the laboratory at Tadulako University, Adam Malik, Wolfram Lorenz, Surya Tarigan, Muhammad Sigit, and all plantation owners for their help.

\section{References}

Abrahamczyk S, Kessler M, Putra D, Waltert M, Tscharntke T (2008) The value of differently managed cacao plantations for forest birds conservation in Sulawesi, Indonesia. Bird Cons Internat 18:349-362

Aguillar V, Staver C, Milberg P (2003) Weed vegetation response to chemical and manual selective ground cover management in a shaded coffee plantation. Weed Res 43:68-75

Bakker JD (2008) Increasing the utility of indicator species analysis. J Appl Ecol 45:1829-1835

Banful BK, Hauser S, Ofori K, Kumaga FK (2007) Weed biomass dynamics in planted fallow systems in the humid forest zone of southern Cameroon. Agroforest Syst 71:49-55

Bhagwat SA, Willis KJ, Birks HJB, Whittaker RJ (2008) Agroforestry: a refuge for tropical biodiversity? Trends Ecol Evol 5:261-267

Bisseleua D, Herve B, Vidal S (2008) Plant biodiversity and vegetation structure in traditional cocoa forest gardens in southern Cameroon under different management. Biodiv Conserv 17:1821-1835

Bloker BM, Brooks ME, Clark CJ, Geange SW, Poulsen JR, Stevens MHH, White JSS (2009) Generalized linear mixed models: a practical guide for ecology and evolution. Trends Ecol Evol 24:127-135

Bobo KS, Waltert M, Sainge NM, Njokagbor J, Fermon H, Mühlenberg M (2006) From forest to farmland: species richness patterns of trees and understory plants along a gradient of forest conversion in Southwestern Cameroon. Biodiv Conserv 15:4097-4117

Bos MM, Dewenter IS, Tscharntke T (2007) The contribution of cacao agroforests to the conservation of lower canopy ant and beetle diversity in Indonesia. Biodiv Conserv 16:2429-2444

Chiarucci A, Enright NJ, Perry GLW, Miller BP, Lamont BB (2003) Performance of nonparametric species richness estimators in high diversity plant community. Divers Distrib 9:283-295
Cicuzza D, Kessler M, Clough Y, Pitopang R, Leitne D, Tjitrosoedirdjo SS (2011) Conservation value of cacao agroforests for terrestrial herbaceous plants in Central Sulawesi, Indonesia. Biotropica. doi:10.1111/j.1744-7429.2010.00741.x

Clarke KR, Somerfield PJ, Gorley RN (2008) Testing of null hypothesis in explanatory community analyses: similarity profile and biota-environment linkage. J Exp Mar Boil Ecol 366:56-69

Clough Y, Putra DD, Pitopang R, Tscharntke T (2009) Local and landscape factors determine functional bird diversity in Indonesian cacao agroforestry. Biol Conserv 142:10321041

Clough Y, Barkmann J, Juhrbandt J, Kessler M, Wanger TC, Anshary A, Buchori D, Cicuzza D, Darras K, Putra DD, Erasmi S, Pitopang R, Schmidt C, Schulze CH, Seidel D, Steffan-Dewenter I, Stenchly K, Vidal S, Weist M, Wielgoss AC, Tscharntke T (2011) Combining high biodiversity with high yields in tropical agroforests. PNAS 108:8311-8316

Colwell RK (2008) EstimateS: Statistical estimation of species richness and shared species from samples. Version 8.0.0 User's guide and application. Available at: http://purl. oclc.org/estimates

Donald PF (2004) Biodiversity impacts of some agricultural commodity production systems. Conserv Biol 18:17-37

Efthimiadou AP, Anestis C, Dimitrios BJ, Efthimiadis P (2009) The phenomenon of crop-weed competition; a problem or a key for sustainable weed management? J Food Agric Environ 7:861-868

Erasmi S, Twele A, Ardiansyah M, Malik A, Kappas SM (2004) Mapping deforestation and land cover conversion at the rainforest margin in Central Sulawesi, Indonesia. EARSeL e Proc 3:388-397

Esmail S, Oelbermann M (2011) The impact of climate change on the growth of tropical agroforestry tree seedlings. Agroforest Syst. doi:10.1007/s10457-011-9424-1

Faria D, Baumgarten J (2007) Shade cacao plantations (Theobroma cacao) and bat conservation in southern Bahia. Brazil Biodiv Conserv 16:291-312

Greenberg R, Bichier P, Angón AC (2000) The conservation value for birds of cacao plantations with diverse planted shade in tabasco. Mexico Anim Conserv 3:105-112

Herzog SK, Kessler M, Cahill TM (2002) Estimating species richness of tropical bird communities from rapid assessment data. Auk 119:749-769

Jose S (2009) Agroforestry for ecosystem services and environmental benefits: an overview. Agroforest Syst 76:1-10

Kessler M, Kessler PJA, Gradstein SR, Bach K, Schmull M, Pitopang R (2005) Tree diversity in primary forest and different land use systems in Central Sulawesi, Indonesia. Biodiv Conserv 14:547-560

Klein AM, Dewenter IS, Tscharntke T (2003) Fruit set of highland coffee increases with the diversity of pollinating bees. Proc R Soc London B 270:955-961

Lozada T, Koning de GHJ, Kessler M, Klein AM, Tscharntke T (2008) Geographical range size of tropical plants influences their response to anthropogenic activities. Div Distrib 14: 59-68

Mc Cune Mefford (1999) PC-ORD Multivariate analysis of ecological data. Version 5. MjM Software Design, Gleneden Beach OR 
Mouillon D, Culioli JM, Chi TD (2002) Indicator species analysis as a test of non-random distribution of species in the context of marine protected areas. Envir Conserv 29:385-390

Oksanen J, Kindt R, Legendre P, O'Hara B, Stevens MHH (2007) Vegan: community ecology package. R package version 1.8-8 http://r-forge.rproject.org/project/vegan/

Partey ST (2011) Effect of pruning frequency and pruning height on the biomass production of Tithonia diversifolia (Hemsl) A. Gray. Agroforest Syst. doi:10.1007/s10457010-9367-y

Perfecto I, Snelling R (1995) Biodiversity and the transformation of a tropical agroecosystem: ants in coffee plantations. Ecol Appl 5:1084-1097

Philpott SM, Armbrecht I (2006) Biodiversity in tropical agroforests and the ecological role of ants and ant diversity in predatory function. Ecol Entomol 31:369-377

Philpott SM, Arendt WJ, Armbrecht I, Bichier P, Diestch TV, Gordon C, Greenberg R, Perfecto I, Reynoso-Santos R, Soto-Pinto L, Tejeda-Cruz C, Williams-Lenera G, Valenzuela J, Zolotoff JM (2008) Biodiversity loss in Latin American coffee landscape: review of the evidence on ants, birds and trees. Conserv Biodiv 22:1093-1105

$\mathrm{R}$ development core team (2007) R: a language and environment for statistical computing. R Foundation for Statistical Computing, Vienna, Austria. http://www.r-project.org

Rice RA, Greenberg R (2000) Cacao cultivation and the conservation of biological diversity. Ambio 29:167-173

Saito K, Linquist B, Johnson DE, Phengchanh S, Shiraiwa T, Horie T (2008) Planted legume fallows reduce weeds and increase soil $\mathrm{N}$ and $\mathrm{P}$ contents but not upland rice yields. Agroforest Syst 74:63-72

Siebert SF (2000) Survival and growth of rattan intercropped with coffee and cacao in the agroforests of Indonesia. Agroforest Syst 50:95-102

Smiley SL, Kroschel J (2010) Yield development and nutrient dynamics in cocoa-gliricidia agroforests of Central Sulawesi, Indonesia. Agroforest Syst 78:97-114

Steffan-Dewenter I, Kessler M, Barkmann J, Bos MM, Buchori D, Erasmi S, Faust H, Gerold G, Glenk K, Gradstein RS,
Guhardja E, Harteveld M, Hertel D, Höhn P, Kappas M, Köhler S, Leuschner C, Maertens M, Marggraf R, MiggeKleian S, Mogea J, Pitopang R, Schafer M, Schwarze S, Sporn SG, Steingrebe A, Tjitrosoedirdjo SS, Tjitrosoedirdjo S, Twele A, Weber R, Woltmann L, Zeller M, Tscharntke T (2007) Tradeoffs between income, biodiversity, and ecosystem functioning during tropical rainforest conversion and agroforestry intensification. PNAS 12:4973-4978

The Nature Conservation (2004) Lore Lindu national park management plan 2004-2029

Tscharntke T, Sekercioglu CH, Dietsch TV, Sodhi NS, Hoehn P, Tylianakis JM (2008) Landscape constraints of functional diversity of birds and insects in tropical agroecosystems. Ecology 89:944-951

Wanger TC, Saro A, Iskandar DT, Brook BW, Sodhi NS, Clough Y, Tscharntke T (2009) Conservation value of cacao agroforestry for amphibians and reptiles in Southeast Asia: combining correlative models with follow-up field experiments. J Appl Ecol 46:823-832

Watanabe A, Takada Sarno H, Afandi, Adachi T, Oki Y, Senge M (2007) Assessment of degradation and generation of humus in a coffee soil affected by weed cover by means of a stable carbon isotopic ratio. Europ J Soil Sci 58:1042-1049

Weist M, Tscharntke T, Sinaga MH, Maryanto I, Clough Y (2010) Effect of distance to forest and habitat characteristics on endemic versus introduced rat species in agroforest landscapes of Central Sulawesi, Indonesia. Mammalian Biol 75:567-571

Wielgoss A, Tscharntke T, Bucheri D, Fiala B, Clough Y (2010) Temperature and a dominant dolichoderine and species affect and diversity in Indonesian cacao plantations. Agr Ecosyst Environ 135:253-259

Zapfack L, Engwald S, Sonke B, Achoundong G, Madong BA (2002) The impact of land conversion on plant biodiversity in the forest zone of Cameroon. Biodiv Conserv 11:20472061 